\title{
Hypothesis
}

\section{Prediction of kinase-inhibitor binding affinity using energetic parameters}

\author{
Singaravelu Usha and Samuel Selvaraj*
}

Department of Bioinformatics, School of Life Sciences, Bharathidasan University, Tiruchirappalli - 620 024, Tamilnadu, India. Dr. Samuel Selvaraj - Email: selvarajsamuel@gmail.com; Mobile: +919894390363; *Corresponding author

Received May 13, 2016; Revised May30, 2016; Accepted May 30, 2016; Published June 15, 2016

\begin{abstract}
The combination of physicochemical properties and energetic parameters derived from protein-ligand complexes play a vital role in determining the biological activity of a molecule. In the present work, protein-ligand interaction energy along with logP values was used to predict the experimental $\log \left(\mathrm{IC}_{50}\right)$ values of 25 different kinase-inhibitors using multiple regressions which gave a correlation coefficient of 0.93 . The regression equation obtained was tested on 93 kinase-inhibitor complexes and an average deviation of 0.92 from the experimental $\log \mathrm{IC}_{50}$ values was shown. The same set of descriptors was used to predict binding affinities for a test set of five individual kinase families, with correlation values $>0.9$. We show that the protein-ligand interaction energies and partition coefficient values form the major deterministic factors for binding affinity of the ligand for its receptor.
\end{abstract}

Keywords: Inhibition constant prediction, Protein-ligand interaction, energetic and solvent descriptors, Kinase inhibitors

\section{Background:}

Protein kinases are a large family of homologous proteins with more than 500 members in the human proteome [1]. Kinasemediated protein phosphorylation is a crucial component of the signal transduction pathways which plays a central role in diverse biological processes such as cell growth, metabolism, differentiation, and apoptosis [2]. A number of diseases, including cancer, diabetes, inflammation, immune and neurodegenerative disorders are linked to perturbation of protein kinase-mediated cell signaling pathways [3]. Since all members of the kinase families utilize ATP, kinase inhibitors are designed to bind with the ATP to prevent substrate phosphorylation [1].

Over 20 small-molecule protein kinase inhibitors have been currently approved and more than 150 kinase inhibitors are undergoing clinical trials [4]. Yet, issues such as target specificity, [5-8] resistance development [9-10] hinge region binding and activation state dependence of kinase inhibitors need to be addressed [2-4].

The three-dimensional structures of proteins with bound ligand are available in the Protein Data Bank [11] along with their experimental binding affinity information. Binding affinity data such as $\mathrm{Ki}, \mathrm{Kd}, \mathrm{IC}_{50}$ etc. obtained from experimental studies are also available in databases such as BindingDB [12], Binding MOAD [13], PDBbind [14] etc. Availability of valuable resources regarding kinase inhibitors made computational biologists to develop statistical models to accurately predict the binding affinity of complexes.

Structure-based virtual screening methods use docking programs to explore the possible binding modes of a ligand within the target binding site, and scoring functions to estimate the affinity of the ligand for the binding site $[15,16]$. While docking methods at present are in general successful in predicting the correct 
binding conformations of ligand molecules, they do not perform well in correctly predicting the binding affinity for the predicted ligand conformations [2]. Hence, it is essential to predict the binding affinity of a given ligand to its target known as the 'scoring problem' [17].

Table 1: Experimentally observed and predicted $\mathrm{IC}_{50}$ values for 25 kinase-inhibitor complexes.

\begin{tabular}{|c|c|c|c|c|c|}
\hline \multirow[t]{2}{*}{ PDB_ID } & \multirow[t]{2}{*}{ Ligand_ID } & \multirow{2}{*}{$\begin{array}{c}\text { Experimental } \\
\mathrm{IC}_{50}(\mathrm{nM})\end{array}$} & \multirow{2}{*}{$\begin{array}{c}\text { Experimental } \\
\log \left(\mathrm{IC}_{50}\right. \\
(\mathrm{nM})) \\
\end{array}$} & \multicolumn{2}{|c|}{ Predicted $\log \left(\mathrm{IC}_{50}(\mathrm{nM})\right)$} \\
\hline & & & & Back-check & $\begin{array}{c}\text { Jack-knife } \\
\text { test }\end{array}$ \\
\hline $2 \mathrm{I} 6 \mathrm{~A}$ & $5 \mathrm{I} 5$ & 22.8 & 1.36 & $1.33(0.03)$ & $1.30(0.06)$ \\
\hline 2008 & RAJ & 1 & 0.00 & $0.26(-0.26)$ & $0.48(-0.48)$ \\
\hline 4AT3 & LTI & 4 & 0.60 & $0.28(0.32)$ & $0.13(0.47)$ \\
\hline 3SXF & BK5 & 5 & 0.70 & $0.69(0.01)$ & $0.69(0.01)$ \\
\hline $2 \mathrm{C} 1 \mathrm{~A}$ & I5S & 170 & 2.23 & $1.43(0.80)$ & $1.96(0.27)$ \\
\hline 3MB6 & $01 \mathrm{I}$ & 100 & 2.00 & $1.71(0.29)$ & $1.54(0.46)$ \\
\hline 1Y6B & AAX & 38 & 1.58 & $0.85(0.73)$ & $1.90(-0.32)$ \\
\hline $2 \mathrm{~A} 4 \mathrm{~L}$ & RRC & 400 & 2.60 & $2.82(-0.22)$ & $2.90(-0.30)$ \\
\hline 2YAK & OSV & 2 & 0.30 & $0.24(0.07)$ & $0.17(0.13)$ \\
\hline 4GK2 & L66 & 40 & 1.60 & $1.55(0.05)$ & $1.53(0.07)$ \\
\hline $3 \mathrm{POZ}$ & 03P & 23 & 1.36 & $1.65(-0.28)$ & $1.91(-0.55)$ \\
\hline $4 \mathrm{~F} 64$ & 0S8 & 63 & 1.80 & $2.00(-0.20)$ & $2.15(-0.35)$ \\
\hline $3 \mathrm{BZ3}$ & YAM & 1.5 & 0.18 & $0.27(-0.09)$ & $0.33(-0.15)$ \\
\hline 1Q3D & STU & 15 & 1.18 & $1.28(-0.11)$ & $1.34(-0.16)$ \\
\hline $3 \mathrm{C} 1 \mathrm{X}$ & CKK & 45 & 1.65 & $1.01(0.64)$ & $0.68(0.97)$ \\
\hline 3D94 & D94 & 19 & 1.28 & $0.96(0.32)$ & $0.77(0.51)$ \\
\hline $4 \mathrm{BKZ}$ & 1WS & 27 & 1.43 & $1.87(-0.43)$ & $2.20(-0.77)$ \\
\hline $3 \mathrm{HRB}$ & I39 & 21 & 1.32 & $1.80(-0.48)$ & $1.93(-0.61)$ \\
\hline $4 \mathrm{BFV}$ & ZVV & 140 & 2.15 & $1.45(0.70)$ & $0.54(1.61)$ \\
\hline 3LJ3 & WYE & 43 & 1.63 & $2.12(-0.49)$ & $2.74(-1.10)$ \\
\hline 2VGO & AD5 & 500 & 2.70 & $1.93(0.77)$ & 1.39 (1.31) \\
\hline $4 \mathrm{HDC}$ & $13 Y$ & 1.2 & 0.08 & $0.37(-0.29)$ & $0.77(-0.69)$ \\
\hline 1RW8 & 580 & 1320 & 3.12 & $2.96(0.16)$ & $2.84(0.28)$ \\
\hline $3 \mathrm{KRR}$ & DQX & 0.48 & -0.32 & $-0.26(-0.06)$ & $-0.16(-0.16)$ \\
\hline \multirow[t]{2}{*}{$3 \mathrm{MVH}$} & WFE & 0.5 & -0.30 & $0.05(-0.35)$ & $0.19(-0.49)$ \\
\hline & & & $\begin{array}{c}\text { Average } \\
\text { deviation }\end{array}$ & 0.41 & 0.63 \\
\hline
\end{tabular}

Note: The deviation between the predicted and experimental $\mathrm{IC}_{50}$ values is given in parenthesis.

As a pioneering work, Bohm [18] (1994) developed a simple empirical function (LUDI) to estimate the binding constant for a protein-ligand complex of known structure. This empirical scoring function takes into account hydrogen bonds, ionic interactions, the lipophilic protein-ligand contact surface and the number of rotatable bonds in the ligand. Head et al. (1996) in their VALIDATE approach used electrostatic and steric interaction energies, octanol-water partition coefficient, polar and nonpolar contact surfaces, and a term to describe intramolecular flexibility [19]. Following the approach of Bohm, [18] Eldridge et al. [20] (1997) included intramolecular flexibility in ChemScore and Wang et al. [21] (1998) classified hydrogen bonds and included the occurrence of interstitial water molecules in SCORE. Based on the statistical analysis of experimentally observed distributions 


\section{Open access}

and frequencies of distance-dependent protein-ligand atom pair interactions, the potential of mean force (PMF) was obtained which has been used for affinity predictions of large datasets [22]. Based on a larger set of 200 protein-ligand complexes, Wang et al. (2002) developed X-Score [17], consisting of four energy terms including van der Waals interactions, hydrogen bonds, hydrophobic effects and effective rotatable bonds. Docking programs such as FlexX [23] and Surflex [24] use empirical scoring functions by including different empirical energy terms. A large-scale validation of a quantum mechanics based scoring function to predict the binding affinity and binding mode of a diverse set of protein-ligand complexes containing different protein families including aspartic proteases, serine proteases, sugar binding proteins, amino acid binding proteins, and protein kinases was done by Raha and Merz (2004) [25]. LigScore functions [26] have made use of three distinct terms, the van der Waals interaction, the polar attraction between the ligand and protein, and the desolvation penalty attributed to the binding of the polar ligand atoms to the protein to predict the experimental $\mathrm{p} K_{\mathrm{i}}$ values of a diverse set of 118 protein-ligand complexes that span more than seven protein families. CLiBE, a database of computed ligand binding energy (based on molecular mechanics force field) for ligand-receptor three dimensional structures have been developed and a linear correlation between the computed ligand-receptor interaction energy and experimental binding affinity (Kcal $/ \mathrm{mol})$ has been observed [27]. A Program for Energetic Analysis of Receptor-Ligand System (PEARLS) has been developed to compute free energy of protein-ligand complexes [28].

While the above methods use the known three dimensional structures to predict binding affinities, the Quantitative Structure-Activity Relationship (QSAR) methods serve as an alternative way of binding affinity predictions in the absence of 3D structure of target proteins or their complexes with ligands. These methods make use of physicochemical and structural properties (descriptors) of ligands to relate their biological activity using regression methods. Combined QSAR approaches in binding affinity predictions have been recently reported [29, 30].

In the present work, we have correlated the experimental $\mathrm{IC}_{50}$ values (in their logarithmic form) of 25 different kinase-inhibitor complexes with their protein- interaction energy and partition coefficient $(\log \mathrm{P})$ values for multiple regression analysis, which shows a good correlation with the experimental $\mathrm{IC}_{50}$ values. This shows that the protein-ligand interaction energies and $\log P$ values form the major factors that determine the ligand binding affinity of proteins. By incorporating these energetic as well as solvent terms, docking methodologies can be highly successful in predicting the binding affinity for the generated poses of their correct ligand binding modes.

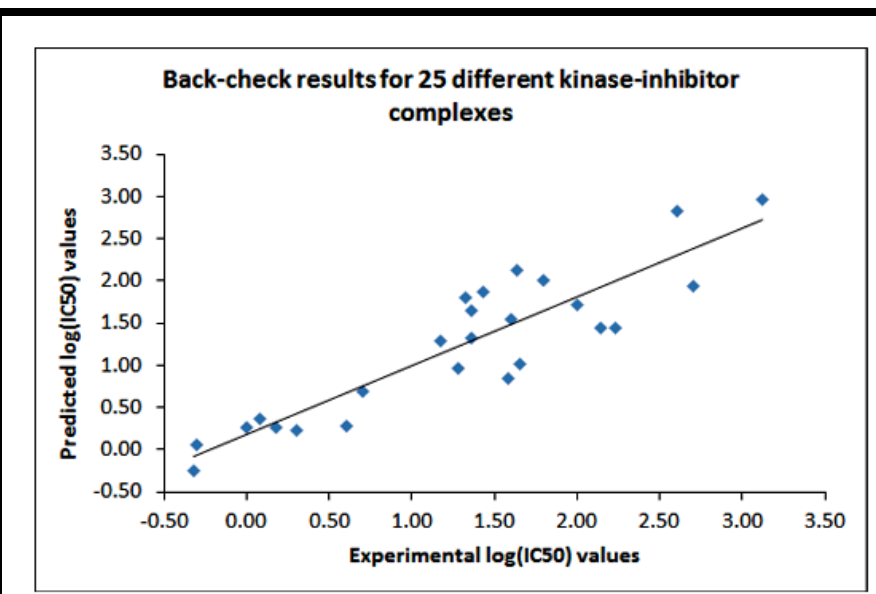

(a)

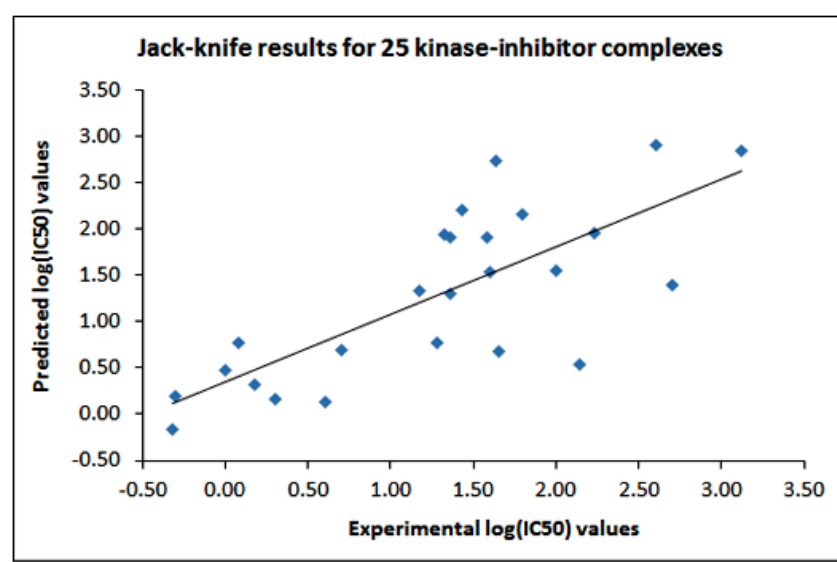

(b)

Figure 1: (a) Scatter plot of experimental and back-check predicted $\mathrm{IC}_{50}$ values in 25 different kinase-inhibitor complexes, (b) Scatter plot of experimental and jack-knife predicted $\mathrm{IC}_{50}$ values in 25 different kinase-inhibitor complexes.

\section{Methodology}

Information resources

Twenty five different protein kinase-inhibitor complexes solved by x-ray crystallography method were obtained from Protein Data Bank [11]. The complexes in the dataset have resolution less than $2.5 \AA$ with known $I_{50}$ values were treated as training set. The number of non-hydrogen atoms of the ligands and energetic profile comprising of i) total ligand-receptor interaction energy, ii) van der Waals energy, iii) electrostatic energy, iv) hydrogen bond energy, v) solvation free energy, vi) conformational entropy and vii) ligand-water-receptor binding energy were obtained from the PEARLS server for each of the kinase-inhibitor complexes. The PEARLS server uses the AMBER force field [31] for computing the above energetic contributions [28]. LogP (octanol/water partition coefficient) values of the ligands were 
calculated from the Molinspiration server [32] by providing SMILES code of the ligand as input.

\section{Training set construction and validation}

Multiple regression analysis was carried out to establish a relationship between the above-mentioned descriptors and experimental $\log \left(\mathrm{IC}_{50}\right)$. A back-check test was carried out for predicting the binding affinity by re-substituting the values in the regression equation obtained. For the jack-knife test, coefficients of multiple regressions were determined using (n-1) data (omitting one protein-ligand complex at a time) and then predicting binding affinity of the omitted protein-ligand complex.

\section{Test set information}

The regression equation obtained from the training set was tested on i) a set of 93 kinase-inhibitor complexes with $\mathrm{IC}_{50}$ values, and ii) a set of 9 approved kinase inhibitors [2].

To further assess the predominant role of the chosen descriptors in binding affinity predictions, the experimental $\log \left(\mathrm{IC}_{50}\right)$ values were regressed with the same set of nine descriptors in five independent protein-kinase families comprising 17 cyclic AMPdependent kinase-inhibitors, 12 casein kinase-inhibitors, 15 hepatocyte growth factor receptor kinase-inhibitors, 12 cyclindependent kinase-inhibitors and 16 mitogen-activated kinaseinhibitors. For each of the five kinase families, five different regression equations were obtained which were then validated by back-check analysis. The dataset information of all the kinaseinhibitor complexes used in the present study, including PDB ID, protein name, ligand ID, x-ray resolution $(\AA)$, experimental $\mathrm{IC}_{50}$ values (nM) with their logarithmic form, and descriptor values are provided in the Appendix.

\section{Discussion}

The following multiple regression equation (1) between $\log \left(\mathrm{IC}_{50}\right)$ values and nine energetic descriptors and $\log \mathrm{P}$ with a correlation coefficient, $r=0.93$ was obtained for the training set of 25 kinaseinhibitor complexes.

$\log \left(\mathrm{IC}_{50}\right)=-0.07 \mathrm{NHA}+44.71 \mathrm{IE}-44.61 \mathrm{vdW}-44.51$ Elect 44.47 H-bonds - 45.45 Solv - 43.19 entropy - 42.82 H-bonds (water-mediated) $+0.18 \log \mathrm{P}+3.58$

where NHA denotes the number of non-hydrogen atoms of the ligand, IE, the total Ligand-receptor interaction energy (Kcal/mol), vdW, the van der Waals energy (Kcal/mol), Elect, the electrostatic Energy (Kcal/mol), H-bonds, the hydrogen bond energy $(\mathrm{Kcal} / \mathrm{mol})$, Solv, the solvation free energy $(\mathrm{Kcal} / \mathrm{mol})$, entropy, the conformational entropy (Kcal/mol), H-bonds (water-mediated), the ligand-water-receptor binding energy (Kcal/mol) and $\log \mathrm{P}$, (the octanol-water) Partition coefficient.

The experimentally observed and predicted $\mathrm{IC}_{50}$ values for 25 kinase-inhibitor complexes in back-check and jack-knife predictions are provided in Table 1 . The average deviation of the predicted $\log \left(\mathrm{IC}_{50}\right)$ values from the experimental $\log \left(\mathrm{IC}_{50}\right)$ values was 0.41 for back-check and 0.63 for jack-knife predictions respectively. The relationship between the experimental $\log \left(\mathrm{IC}_{50}\right)$ values with back-check and jack-knife predictions are provided as scatter plots in Figure 1a and $\mathbf{1 b}$.

Table 2: Prediction of experimental $\log \left(\mathrm{IC}_{50}\right)$ values in approved kinase inhibitors.

\begin{tabular}{|c|c|c|c|c|c|c|}
\hline $\begin{array}{l}\text { S. } \\
\text { NO. }\end{array}$ & PDB ID & Protein name & $\begin{array}{l}\text { Ligand } \\
\text { ID }\end{array}$ & Ligand name & $\begin{array}{r}\text { Experimental } \\
\log \left(\mathrm{IC}_{50}(\mathrm{nM})\right)\end{array}$ & $\begin{array}{c}\text { Predicted } \\
\log \left(\mathrm{IC}_{50}\right. \\
(\mathrm{nM}))\end{array}$ \\
\hline 1 & 1M17 & Epidermal growth factor receptor & AQ4 & Erlotinib & $-0.70-3.16(1.23)$ & 0.87 \\
\hline 2 & 1IEP & Proto-oncogene tyrosine-protein kinase abl & STI & Imatinib & $0.04-3.93(1.99)$ & 1.79 \\
\hline 3 & 2ITY & Epidermal growth factor receptor & IRE & Gefitinib & $0.00-3.44(1.72)$ & 1.46 \\
\hline 4 & $2 \mathrm{~J} 2 \mathrm{I}$ & $\begin{array}{l}\text { Proto-oncogene serine/threonine-protein kinase } \\
\text { pim-1 }\end{array}$ & LY4 & Ruboxistaurin & 2.30 & 1.61 \\
\hline 5 & 2GQG & Proto-oncogene tyrosine-protein kinase abl1 & $1 \mathrm{~N} 1$ & Dasatinib & $-0.70-2.85(1.07)$ & -0.97 \\
\hline 6 & 2JAV & Serine/threonine-protein kinase nek2 & $5 Z 5$ & Sunitinib & 3.90 & 1.02 \\
\hline 7 & $1 \mathrm{UWH}$ & $\begin{array}{l}\text { B-raf proto-oncogene serine/threonine-protein } \\
\text { kinase }\end{array}$ & BAX & Sorafenib & $1.04-3.86(2.45)$ & 1.12 \\
\hline 8 & $1 \mathrm{XKK}$ & Epidermal growth factor receptor & FMM & Lapatinib & $0.46-2.64(1.55)$ & 1.88 \\
\hline 9 & $2 \mathrm{~F} 2 \mathrm{U}$ & Rho-associated protein kinase 2 & M77 & Fasudil & $2.26-4.07(3.16)$ & 2.45 \\
\hline
\end{tabular}

Note: The mean value between the logarithm of minimum and maximum experimental $\mathrm{IC}_{50}$ values are given in parenthesis. 


\section{BIOINFORMATION}

Discovery at the interface of physical and biological sciences

\section{Open access}

Table 3: Experimentally observed and predicted $\mathrm{IC}_{50}$ values for 17 cyclic AMP-dependent protein kinase-inhibitor complexes.

\begin{tabular}{ccrcc}
\hline PDB_ID & LIG_ID & $\begin{array}{c}\text { Experimental } \\
\text { IC }_{50}(\mathbf{n M})\end{array}$ & $\begin{array}{c}\text { Experimental } \\
\log \left(\mathbf{I C}_{50}(\mathbf{n M})\right)\end{array}$ & $\begin{array}{c}\text { Back-check } \\
\text { Prediction }\end{array}$ \\
\hline 1STC & STU & 51 & 1.71 & $1.45(0.26)$ \\
1SVE & I01 & 5 & 0.70 & $0.99(-0.29)$ \\
1XH4 & R69 & 30 & 1.48 & $1.58(-0.10)$ \\
1YDS & IQS & 5300 & 3.72 & $3.13(0.59)$ \\
2C1A & I5S & 170 & 2.23 & $2.23(0.00)$ \\
2F7X & 4EA & 38 & 1.58 & $1.64(-0.06)$ \\
2GNI & M77 & 7605 & 3.88 & $3.59(0.29)$ \\
2JDS & L20 & 27 & 1.43 & $1.45(-0.01)$ \\
2OH0 & 2PY & 18 & 1.26 & $1.21(0.04)$ \\
2OJF & 4PY & 110 & 2.04 & $2.15(-0.11)$ \\
2UW6 & GVO & 280 & 2.45 & $3.07(-0.62)$ \\
2UZT & SS3 & 14 & 1.15 & $1.11(0.04)$ \\
3L9L & L9L & 167 & 2.22 & $1.78(0.45)$ \\
3MVJ & XFE & 3200 & 3.51 & $3.77(-0.27)$ \\
3OW3 & SMY & 742 & 2.87 & $2.88(-0.01)$ \\
3ZO2 & 15I & 80 & 1.90 & $2.10(-0.19)$ \\
4C35 & NU3 & 560 & 2.75 & $2.76(-0.01)$ \\
\hline & & & Average deviation & $\mathbf{0 . 2 8}$ \\
\hline
\end{tabular}

Note: The deviation between the predicted and experimental $\mathrm{IC}_{50}$ values is given in parenthesis.

Table 4: Experimentally observed and predicted $\mathrm{IC}_{50}$ values for 12 casein kinase-inhibitor complexes.

\begin{tabular}{ccrcc} 
PDB_ID & LIG_ID & $\begin{array}{c}\text { Experimental } \\
\text { IC }_{\mathbf{5 0}}(\mathbf{n M})\end{array}$ & $\begin{array}{c}\text { Experimental } \\
\mathbf{l o g}\left(\mathbf{I C}_{\mathbf{5 0}}(\mathbf{n M})\right)\end{array}$ & $\begin{array}{c}\text { Back-check } \\
\text { Prediction }\end{array}$ \\
\hline 2QC6 & G12 & 100 & 0.27 & $0.24(0.03)$ \\
2ZJW & REF & 40 & 0.38 & $0.37(0.01)$ \\
3AMY & AGI & 800 & 0.36 & $0.38(-0.02)$ \\
3BQC & EMO & 2000 & 0.18 & $0.20(-0.03)$ \\
3MB6 & 01I & 100 & 0.24 & $0.25(0.00)$ \\
3PE1 & 3NG & 1 & 0.20 & $0.21(-0.01)$ \\
3PWD & CZ0 & 220 & 0.34 & $0.31(0.03)$ \\
3R0T & FU9 & 0.91 & 0.24 & $0.24(0.01)$ \\
3RPS & 4B0 & 320 & 0.36 & $0.37(-0.01)$ \\
3U4U & LNH & 3100 & 0.34 & $0.34(0.01)$ \\
4ANM & WUL & 28 & 0.23 & $0.22(0.01)$ \\
4DGM & AGI & 1200 & 0.22 & $0.23(-0.02)$ \\
\hline
\end{tabular}

Average deviation

0.02

Note: The deviation between the predicted and experimental $\mathrm{IC}_{50}$ values is given in parenthesis.

ISSN 0973-2063 (online) 0973-8894 (print) 


\section{Open access}

a) Test set of diverse protein kinases (Test set I)

The regression equation (1) obtained was tested on 93 kinaseinhibitor complexes (results are provided as Table 7 in the Supporting Information file) and the relationship between the experimental and predicted $\log \left(\mathrm{IC}_{50}\right)$ values is presented as a scatter plot (Figure 2). An average deviation of 0.92 from the original $\log \left(\mathrm{IC}_{50}\right)$ values was observed for the 93 kinase-inhibitor complexes. The difference between the experimental and calculated $\log \left(\mathrm{IC}_{50}\right)$ values was found to be less than $\pm 1 \log$ unit for 64 out of 93 kinase-inhibitor complexes.

\section{b) Approved kinase inhibitors as test set (Test set II)}

To further test the predictability of our regression equation (1), we have tested it for nine approved kinase inhibitors ${ }^{2}$. The experimental values of those inhibitors were found to have minimum and maximum range of values. Hence, the mean value between the logarithm of minimum and maximum values were calculated and compared with the predicted values. The predicted values were almost closer (the deviation was less than 1) to the experimental $\log \left(\mathrm{IC}_{50}\right)$ values in 7 out of 9 kinaseinhibitor complexes (Table 2).

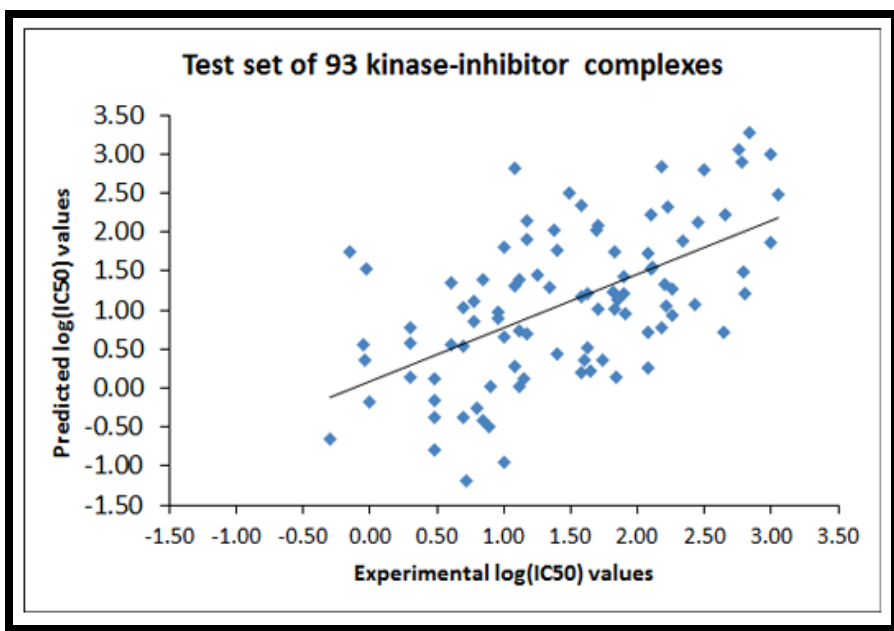

Figure 2: Scatter plot of experimental and predicted $\mathrm{IC}_{50}$ values in the test set of 93 kinase-inhibitor complexes.

\section{c) Kinase classes}

In order to further validate the use of the same set of descriptors in predicting binding affinity, the experimental $\mathrm{IC}_{50}$ values of five kinase families were regressed. The regression equation obtained for individual kinase families and the result of back-check predictions are discussed as follows:

\section{i) Cyclic AMP-dependent protein kinase-inhibitor complexes} For a data-set of 17 cyclic AMP-dependent protein kinaseinhibitor complexes, a correlation value of 0.95 was obtained using the regression equation (2) $\log \left(\mathrm{IC}_{50}\right)=-0.06 \mathrm{NHA}-76.09 \mathrm{IE}+76.08 \mathrm{vdW}+75.98$ Elect + 76.26 H-bonds +76.62 Solv +75.21 entropy +77.07 H-bonds (water-mediated) $-0.13 \log P+5.21$

Using the regression equation (Eq. 2), $\log \left(\mathrm{IC}_{50}\right)$ values for 17 cyclic AMP-dependent protein kinase-inhibitor complexes were predicted. The experimental as well as predicted $\log \left(\mathrm{IC}_{50}\right)$ values are presented (Table 3) and plotted (Figure 3a). The average deviation for the back-check test was 0.28 from the experimental values.

\section{ii) Casein kinase-inhibitor complexes}

12 casein kinase-inhibitor complexes were taken for the multiple regression analysis which has shown a good correlation of $\mathrm{r}=$ 0.97 for the regression equation (3)

$\log \left(\mathrm{IC}_{50}\right)=0.01 \mathrm{NHA}-1.40 \mathrm{IE}+1.45 \mathrm{vdW}+1.39$ Elect $+1.36 \mathrm{H}-$ bonds +1.43 Solv +1.35 entropy +1.69 H-bonds (watermediated) $+0.01 \log P+0.47$

The set of 12 casein kinase-inhibitor complexes with their experimental and predicted values has been provided (Table 4). The scatter plot shows the relationship between the experimental and predicted $\mathrm{IC}_{50}$ values (Figure $3 \mathbf{b}$ ), the average deviation being 0.02 for back-check predictions.

iii) Hepatocyte growth factor receptor kinase-inhibitor complexes

A set of 15 hepatocyte growth factor receptor kinase-inhibitors has shown a correlation coefficient value of 0.90 when subjected to regression with multiple descriptors, the equation (4) being

$\log \left(\mathrm{IC}_{50}\right)=0.05 \mathrm{NHA}-232.16 \mathrm{IE}+231.87 \mathrm{vdW}+231.02$ Elect + 232.03 H-bonds +232.68 Solv +224.75 entropy $+236.13 \mathrm{H}$-bonds (water-mediated) $-0.27 \log \mathrm{P}+0.24$

The experimental and predicted $\log \left(\mathrm{IC}_{50}\right)$ values are provided in Table 5. The correlation between experimental and calculated values for the 15 hepatocyte growth factor receptor kinaseinhibitors is shown in Figure 3c. An average deviation of 0.31 was observed.

\section{iv) Cyclin-dependent kinase-inhibitor complexes}

A very good correlation of $r=0.94$ was obtained for 12 cyclindependent kinase-inhibitor dataset using the regression equation (5)

$\log \left(\mathrm{IC}_{50}\right)=-0.35 \mathrm{NHA}+94.15 \mathrm{IE}-94.18 \mathrm{vdW}$ - 96.24 Elect 92.97 H-bonds - 92.06 Solv -96.77 entropy - 95.47 H-bonds (water-mediated) $+1.94 \log \mathrm{P}+6.27$

The predicted results of 12 cyclin-dependent kinase-inhibitor complexes are tabulated (Table 6). The average deviation value from the experimental value was found to be 0.49 . The results are plotted (Figure 3d). 


\section{BIOINFORMATION}

Discovery at the interface of physical and hiological sciences

\section{Open access}

Table 5: Experimentally observed and predicted $\mathrm{IC}_{50}$ values for 15 hepatocyte growth factor receptor kinase-inhibitor complexes.

\begin{tabular}{|c|c|c|c|c|}
\hline PDB_ID & LIG_ID & $\begin{array}{l}\text { Experimental } \\
\qquad \mathrm{IC}_{50}(\mathrm{nM})\end{array}$ & $\begin{array}{l}\text { Experimental } \\
\log \left(\mathrm{IC}_{50}(\mathrm{nM})\right)\end{array}$ & $\begin{array}{l}\text { Back-check } \\
\text { Prediction }\end{array}$ \\
\hline 2WD1 & $\mathrm{ZZY}$ & 82 & 1.91 & $1.56(0.36)$ \\
\hline 2WKM & PFY & 9 & 0.95 & $1.26(-0.30)$ \\
\hline $3 \mathrm{C} 1 \mathrm{X}$ & CKK & 45 & 1.65 & $1.56(0.09)$ \\
\hline $3 \mathrm{CCN}$ & LKG & 120 & 2.08 & $1.69(0.39)$ \\
\hline 3CD8 & L5G & 9 & 0.95 & $1.11(-0.16)$ \\
\hline 3СТH & 319 & 35 & 1.54 & $1.84(-0.29)$ \\
\hline $3 \mathrm{I} 5 \mathrm{~N}$ & $\mathrm{~B} 2 \mathrm{D}$ & 17 & 1.23 & $1.69(-0.46)$ \\
\hline $3 F 66$ & IHX & 900 & 2.95 & $2.88(0.07)$ \\
\hline $3 \mathrm{~L} 8 \mathrm{~V}$ & L8V & 8 & 0.90 & $0.72(0.18)$ \\
\hline 3QTI & 3QT & 14 & 1.15 & $1.18(-0.04)$ \\
\hline 3RHK & M97 & 520 & 2.72 & $2.60(0.11)$ \\
\hline 4DEG & $0 \mathrm{JJ}$ & 6 & 0.78 & $1.43(-0.65)$ \\
\hline $4 \mathrm{DEH}$ & 0JK & 612 & 2.79 & $2.71(0.08)$ \\
\hline 4EEV & L1X & 42 & 1.62 & $1.09(0.53)$ \\
\hline 4GG7 & $0 \mathrm{~J} 8$ & 6.5 & 0.81 & $0.72(0.09)$ \\
\hline \multicolumn{4}{|r|}{ Average deviation } & 0.31 \\
\hline
\end{tabular}

Table 6: Experimentally observed and predicted $\mathrm{IC}_{50}$ values for 12 cyclin-dependent kinase-inhibitor complexes.

\begin{tabular}{lclrcc}
\hline PDB_ID & LIG_ID & PDB_ID & $\begin{array}{r}\text { Experimental } \\
\mathbf{I C}_{50}(\mathbf{n M})\end{array}$ & $\begin{array}{c}\text { Experimental } \\
\mathbf{l o g}\left(\mathbf{I C}_{50}(\mathbf{n M})\right)\end{array}$ & $\begin{array}{c}\text { Back-check } \\
\text { Prediction }\end{array}$ \\
\hline 1AQ1 & STU & 1AQ1 & 7 & 0.85 & $0.71(0.13)$ \\
1DI8 & DTQ & 1DI8 & 1000 & 3.00 & $3.07(-0.07)$ \\
1E1X & NW1 & 1E1X & 2200 & 3.34 & $3.89(-0.54)$ \\
1H01 & FAL & 1H01 & 22000 & 4.34 & $4.74(-0.40)$ \\
1W0X & OLO & 1W0X & 7 & 0.85 & $1.59(-0.74)$ \\
3S2P & PMU & 3S2P & 68 & 1.83 & $1.36(0.48)$ \\
3TIY & TIY & 3TIY & 17000 & 4.23 & $4.36(-0.13)$ \\
3TNW & F18 & 3TNW & 20000 & 4.30 & $3.52(0.78)$ \\
3ULI & 1N3 & 3ULI & 70 & 1.85 & $1.48(0.37)$ \\
3UNJ & 0BX & 3UNJ & 11000 & 4.04 & $3.41(0.63)$ \\
3WBL & PDY & 3WBL & 23000 & 4.36 & $4.22(0.14)$ \\
$4 B G H$ & 3I6 & $4 B G H$ & 4 & 0.60 & $1.24(-0.63)$ \\
\hline & & & & Average deviation & $\mathbf{0 . 4 9}$ \\
\hline
\end{tabular}

Note: The deviation between the predicted and experimental $\mathrm{IC}_{50}$ values is given in parenthesis. 
Table 7: Experimentally observed and predicted $\mathrm{IC}_{50}$ values for 16 mitogen-activated protein kinase-inhibitor complexes

\begin{tabular}{|c|c|c|c|c|}
\hline PDB_ID & LIG_ID & $\begin{array}{c}\text { Experimental } \\
\text { IC }_{50}(\mathrm{nM})\end{array}$ & $\begin{array}{r}\text { Experimental } \\
\log \left(\mathrm{IC}_{50}(\mathrm{nM})\right)\end{array}$ & $\begin{array}{l}\text { Back-check } \\
\text { Prediction }\end{array}$ \\
\hline 1W82 & L10 & 196 & 2.29 & $2.40(-0.11)$ \\
\hline $1 \mathrm{WBN}$ & L09 & 350 & 2.54 & $2.20(0.34)$ \\
\hline $1 Z Y J$ & BI5 & 1500 & 3.18 & $2.84(0.33)$ \\
\hline $3 F L Z$ & FLZ & 106 & 2.03 & $2.25(-0.22)$ \\
\hline 3FMH & 533 & 11 & 1.04 & $1.25(-0.21)$ \\
\hline 3HL7 & $\mathrm{I} 47$ & 110 & 2.04 & $1.56(0.48)$ \\
\hline 3HP2 & P36 & 680 & 2.83 & $3.07(-0.24)$ \\
\hline 3HRB & I39 & 21 & 1.32 & $1.99(-0.67)$ \\
\hline $3 \mathrm{IPH}$ & G11 & 316.23 & 2.50 & $2.40(0.10)$ \\
\hline 3L8X & N4D & 10 & 1.00 & $0.96(0.04)$ \\
\hline $3 \mathrm{MVM}$ & $39 \mathrm{P}$ & 3.9 & 0.59 & $0.63(-0.03)$ \\
\hline 3NWW & $3 \mathrm{NW}$ & 7 & 0.85 & $0.96(-0.12)$ \\
\hline $3 S 4 Q$ & NK0 & 4 & 0.60 & $0.44(0.16)$ \\
\hline $3 U V P$ & 048 & 35 & 1.54 & $1.26(0.28)$ \\
\hline 3ZSG & $\mathrm{T} 75$ & 7.1 & 0.85 & $1.15(-0.30)$ \\
\hline \multirow[t]{2}{*}{ 4EWQ } & GG5 & 600 & 2.78 & $2.62(0.16)$ \\
\hline & & & $\begin{array}{c}\text { Average } \\
\text { deviation }\end{array}$ & 0.29 \\
\hline
\end{tabular}

Note: The deviation between the predicted and experimental $\mathrm{IC}_{50}$ values is given in parenthesis.

\section{v) Mitogen-activated protein kinase-inhibitor complexes}

The multiple regression analysis of 16 mitogen-activated protein kinase-inhibitors gave a correlation of $r=0.94$ using the regression equation (6)

$\log \left(\mathrm{IC}_{50}\right)=-0.13 \mathrm{NHA}+16.62 \mathrm{IE}-16.05 \mathrm{vdW}-17.09$ Elect 16.66 H-bonds - 16.62 Solv - 13.78 entropy - 18.19 H-bonds (water-mediated) $+0.40 \log P+8.27$

The observed and computed values for a dataset of 16 mitogenactivated protein kinase-inhibitors are presented (Table 7) showing an average deviation value of 0.29 . The predicted $\mathrm{IC}_{50}$ values were plotted against the experimental values (Figure 3e).

In QSAR studies, usually a large number of physicochemical and structural properties (descriptors) of chemical compounds are calculated and the best combinations of descriptors that correlate maximally with the biological activity are chosen. QSAR models have been developed for predicting kinase selectivity profiles to provide understanding of structure selectivity relationships for kinase inhibitor design [33-35]. The development of widely accepted 'universal' set of descriptors applicable for diverse datasets has also been a focus of QSAR-based analysis [36-38]. In the present work, a uniform set of descriptors have been used across different kinase-inhibitor complexes for binding affinity prediction.

Han et al. (2006) suggested that the calculated interaction energies highly depend on van der Waals contacts, electrostatic interactions, hydrogen bonds, metal-receptor binding, and solvation [28], which agrees with the observations of our present analysis. These observations are reflected in the interaction energy contributions of our present analysis. The protein-ligand interaction energies obtained using PEARLS server has been used in other studies on inhibitor discovery such as HIV-1 protease [39] and ribonuclease A inhibitors [40] to predict the binding affinity values using regression analysis. $\log P$, remains the main deterministic factor for the ligand's affinity for the protein active site with reference to the surrounding solvent environment [41].

In the present study, we have used the various energetic components as independent variables along with $\log P$ values, to predict the experimental binding affinity. This set of descriptors developed from a small set of 25 kinase-inhibitor complexes were able to predict $\mathrm{IC}_{50}$ values for 93 test set complexes spanning 4 orders of magnitude of $\mathrm{IC}_{50}$ values. The same set of descriptors was also found to be suitable for family specific regression models as well. 


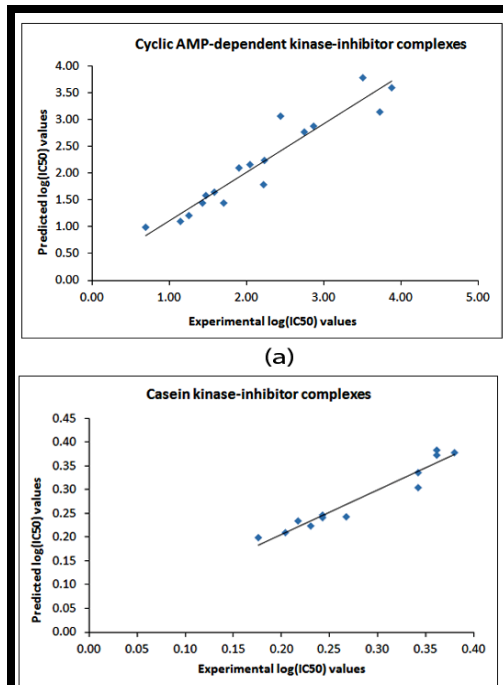

(b)

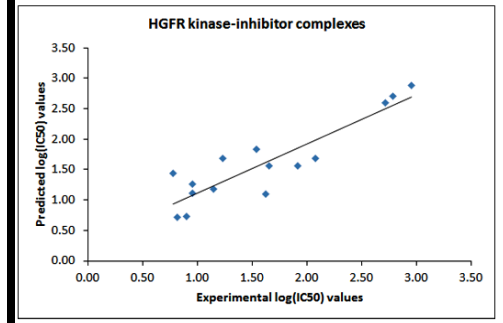

(c)

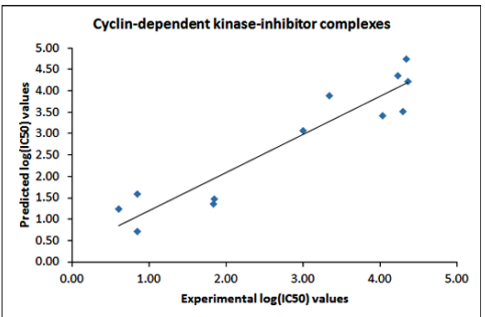

(d)

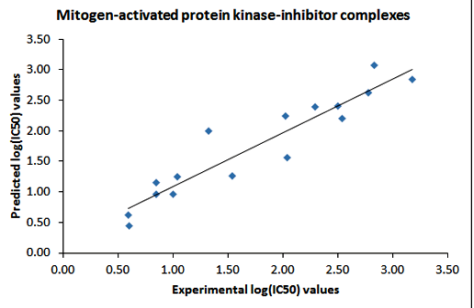

(e)

Figure 3: Scatter plot of experimental and back-check predicted $\mathrm{IC}_{50}$ values in (a) 17 cyclic AMP-dependent kinase-inhibitor complexes; (b) 12 caesin kinase-inhibitor complexes; (c) 15 Hepatocyte growth factor receptor kinase-inhibitor complexes; (d)12 cyclin-dependent kinase-inhibitor complexes; (e) 16 mitogen-activated protein kinase-inhibitor complexes.
As docking methods improve to reproduce conformations observed through x-ray crystallographic and NMR determined structures, it will be possible to use our present approach to predict the $\mathrm{IC}_{50}$ values for various protein targets, more significantly for specific protein families. Alternatively, if $\mathrm{IC}_{50}$ values for kinase-inhibitor complexes are known, the method can also be used to predict the pose of a given ligand as well.

\section{Conclusion:}

Despite intensive research over more than two decades, accurate prediction of the binding affinities of large set of diverse protein ligand complexes remains one of the most important open problems in computational molecular biology [42]. The issues currently being addressed are the scoring of modelled protein conformations, and including the binding free energy due to presence of water molecules [43]. In the present work, we have addressed these issues by using energetic and solvent descriptors to predict the binding affinity of kinase-inhibitor complexes using multiple regression analysis. A high correlation value of 0.9 between the predicted and experimental binding affinity was obtained for a test set of kinase-inhibitor complexes. The method was validated by predicting a test of 93 kinase-inhibitor complexes covering five kinase families which has shown a good predictive ability. Our methodology can provide valuable insights for the prediction accuracy of molecular docking strategies. Further studies will be required to validate the general applicability of these set of descriptors to predict the binding affinity for a diverse set of enzyme-inhibitor complexes.

\section{Acknowledgement:}

SS thanks the University Grants Commission, New Delhi for the award of Emeritus Fellowship (Grant No: F.6-6/ 2014-15/ EMERITUS-2014-15-GEN-4545/ (SA-II)).

\section{References:}

[1] Patricelli MP et al. Biochemistry 2007 46:350 [PMID:17209545]

[2] Ghose AK et al. J Med Chem. 2008 51:5149 [PMID:18710211]

[3] Noble ME et al. Science 2004 303: 1800 [PMID:15031492]

[4] Cohen P \& Alessi DR, ACS Chem Biol. 2013 8: 96 [PMID:23276252]

[5] Feng L et al. J Am Chem Soc. 2011 133: 5976 [PMID:21446733]

[6] Meggers E Angew Chem Int Ed. 2011 50: 2442 [PMID:21328511]

[7] Dar AC \& Shokat KM, Annu Rev Biochem. 2011 80:769 [PMID:21548788]

[8] Endicott JA et al. Annu Rev Biochem. 2012 81:587 [PMID:22482904]

[9] Tamborini E et al. Gastroenterology 2004 127:294 [PMID:15236194]

[10] Cools J et al. Drug Resist Updat. 2005 8:119 [PMID:15869901]

[11] Berman HM et al. Nucleic Acids Res. 2000 28:235 [PMID:10592235]

[12] Liu T et al. Nucleic Acids Res. 2007 35:D198 [PMID:17145705]

[13] Hu L et al. Proteins Struct Funct Bioinf. 2005 60:333 [PMID:15971202] 


\section{BIOINFORMATION}

\section{Discovery at the interface of physical and biological sciences}

\section{Open access}

[14] Wang R et al. J Med Chem. 2004 47:2977 [PMID:15163179]

[15] Leach AR et al. J Med Chem. 2006 49:5851 [PMID:17004700]

[16] Huang SY \& Zou X, Int J Mol Sci. 2010 11:3016 [PMID:21152288 ]

[17] Wang $\mathrm{R}$ et al. J Comput-Aided Mol Des. 2002 16:11 [PMID:12197663]

[18] Böhm HJ J Comput-Aided Mol Des. 1994 8:243 [PMID:7964925]

[19] Head RD et al. J Am Chem Soc. 1996 118:3959

[20] Eldridge MD et al. J Comput-Aided Mol Des. 1997 11:425 [PMID: 9385547]

[21] Wang R et al. J Mol Model. 1998 4:379

[22] Muegge I \& Martin YC, J Med Chem. 1999 42:791 [PMID:10072678]

[23] Rarey M et al. J Mol Biol. 1996 261:470 [PMID:8780787]

[24] Jain AN J Med Chem. 2003 46:499 [PMID:12570372]

[25] Raha K \& Merz KM, J Am Chem Soc. 2004 126:1020 [PMID:14746460]

[26] Krammer A et al. J Mol Graphics Modell. 2005 23:395 [PMID:15781182]

[27] Chen X et al.Comput Chem. 2002 26:661 [PMID:12385480]

[28] Han LY et al. J Chem Inf Model. 2006 46:445 [PMID:16426079]

[29] Verma J et al. Curr Top Med Chem. 2010 10:95 [PMID:19929826]

[30] Martin E et al. J Chem Inf Model. 2011 51:1942 [PMID:21667971]

[31] Weiner SJ et al. J Am Chem Soc. 1984 106:765

[32] www.molinspiration.com/

[33] Anderson DR et al. J Med Chem. 2007 50:2647 [PMID:17480064]

[34] Sheridan RP et al. J Chem Inf Model. 2009 49:1974 [PMID:19639957]

[35] Sciabola S et al.J Chem Inf Model. 2008 48:1851 [PMID:18717582]

[36] Labute P J Mol Graphics Modell. 2000 18:464 [PMID:11143563]

[37] Dominy BN \& Shakhnovich EI, J Med Chem. 2004 47:4538 [PMID:15317465]

[38] Burden FR et al.J Chem Inf Model. 2009 49:710 [PMID: 19434903]

[39] Vijjulatha M \& Kanth SS, Cent Eur J Chem. 2007 5:1064

[40] Samanta A et al. Bioorg Med Chem. 2011 19:2478 [PMID:21420869]

[41] Leo AJ Chem Rev. 1993 93:1281

[42] Ballester PJ et al.J Chem Inf Model. 2014 54:944 [PMID:24528282]

[43] Moitessier N et al. Br J Pharmacol. 2008 153:7 [PMID:18037925]

Edited by P Kangueane Citation: Usha \& Selvaraj, Bioinformation 12(3): 172-181 (2016) License statement: This is an Open Access article which permits unrestricted use, distribution, and reproduction in any medium provided the original work is properly credited. This is distributed under the terms of the Creative Commons Attribution License

\section{BIOMEDICAL}

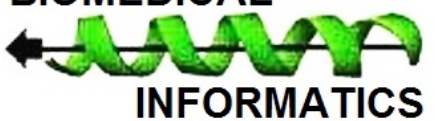

